University of North Florida

UNIVERSITY of

NORTH FLORIDA.

UNF Digital Commons

6-9-2013

\title{
The Great Transition of Scholarly Communication at the Thomas G. Carpenter Library
}

\author{
Alice Eng \\ University of North Florida, enga@wfu.edu \\ Cynthia J. Jordan \\ University of North Florida, cjordan@unf.edu
}

Follow this and additional works at: https://digitalcommons.unf.edu/library_facpub

Part of the Library and Information Science Commons

\section{Recommended Citation}

Eng, Alice and Jordan, Cynthia J., "The Great Transition of Scholarly Communication at the Thomas G. Carpenter Library" (2013). Library Faculty Presentations \& Publications. 30.

https://digitalcommons.unf.edu/library_facpub/30

This Presentation is brought to you for free and open access by the Thomas G. Carpenter Library at UNF Digital Commons. It has been accepted for inclusion in Library Faculty Presentations \& Publications by an authorized administrator of UNF Digital Commons. For more information, please contact Digital Projects.

(c) 6-9-2013 All Rights Reserved

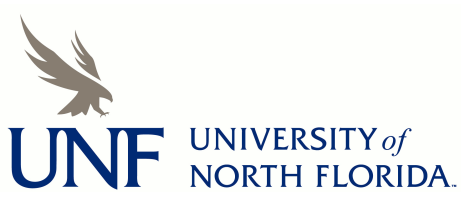




\section{The Great Transition of Scholarly Communication at The Thomas G. Carpenter Library}

- Alice Eng

Electronic Resources Librarian

University of North Florida

- Cynthia J. Jordan

Coordinator of Media Services

University of North Florida 


\section{Promoting Scholarly Communication}

- Digital Commons

- Open Access

- LibGuides 


\section{Digital Commons}

- Over 2400 digital objects

- SelectedWorks and other nontraditional works

- Student scholarship

- Open access journals

- Everything in Digital Commons full text searchable 


\section{Who is UNF's Scholarly Community?}

- Serving more than faculty

- Encourages engagement

- Accessible to anyone

- libguides.unf.edu

- http://digitalcommons.unf.edu/ 


\section{How Works Are Submitted}

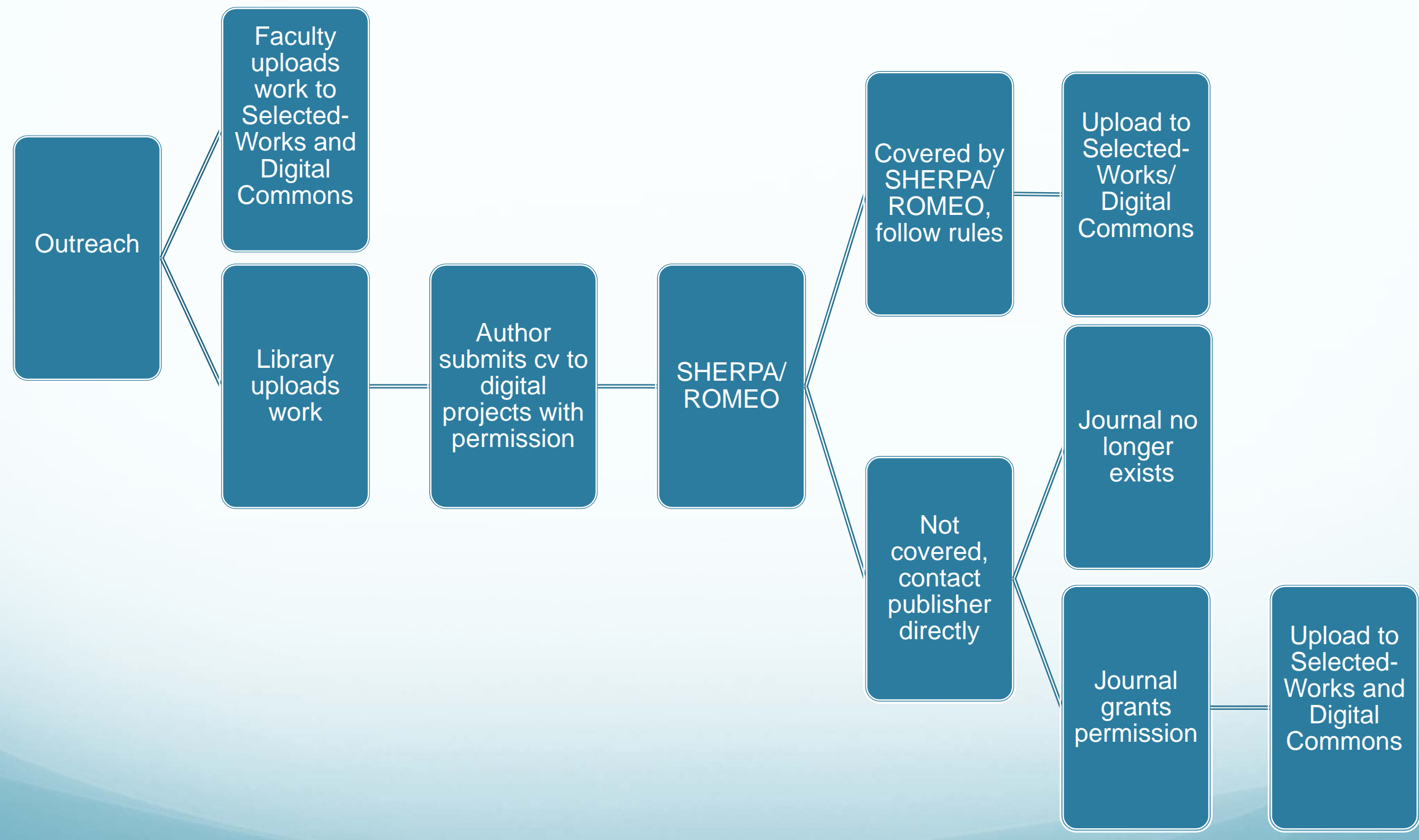


(3) ETD Submission page.jpg (JPEG Image, $1306 \times 4877$ pixels) - Scaled (18\%) - Mozilla Firefox

File Edit View Hiștory Bookmarks Iools Help

My Drive - Google Drive E Scholarly Communication - Google D...

ETD Submission page.jpg (JPEG Imag... $\times$ ETD Detail page.jpg (JPEG Image, 130... $\times$

$\leftarrow$ file:///C:/Users/noob 8. Most Visited (3) Getting Started \&y Dictionary com / Find to. University of North Flo

EZproxy Administration $\$ Library Instruction Cal... $\$ UNF - Information Tec... $\odot$ Database setup [OCLC...

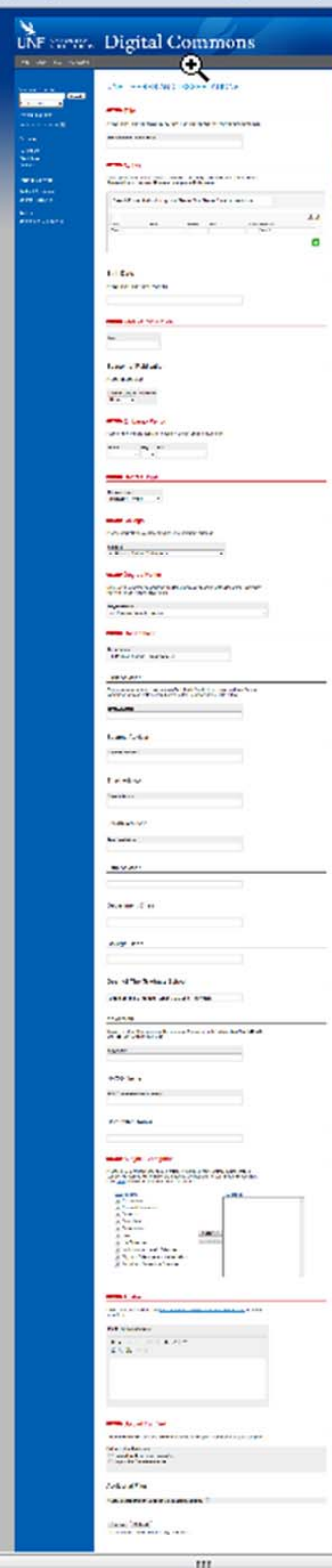


Manage Theses/Dissertations

Upload Thesis/Dissertation Usage Reports Configuration Mailing Lists My Account

Theses/Dissertations

Batch upload XML

Show these theses/dissertations:

(2)

Batch upload Excel

State:

Reviewer List

Reviewer Report

Close ir_etd

LastName show all theses/dissertations

Search

Update site

Go to site

Preferences

Log out

Administrator report

Showing $1-25$ of 28 : $<<<>>>$ show all

ViD Author

1361

1360

1357

1356

1355

1354

1353

352

1351

1350

1349

1346

1344

1340

1333

1314

1306

1304

1303

1301

300

Showing 1 - 25 of 28 : $<<>>>$ show al

\section{Title}

Effect of Blood Collection Pra.

NONTRADITIONAL GRADUATE STUDEN.

THE EFFECTS OF AN INTERVENTION.

Bacteriostatic Effects of Sucr.

Investigation Into The Relatio.

Postsecondary Mathematics Plac.

Creativity across cultures: A

The Role of Social Support and

Cultural Values and Creativity..

ARBOVIRUS PERSISTENCE AND SELE

Adolescent Athletes with Type

Plant-Pathogen Interactions As.

Response of the epiphytic alga.

THE EFFECT OVERALL DENSITY PLA.

It's Personal and Not Just Bus.

Perceptions of Secondary Inten

YOU GET WHAT YOU DESERVE: THE

FLEXURAL BEHAVIOR OF LATERALLY.

Evaluating Speedup in Parallel...

IMPROVEMENTS IN GENETIC APPROA.

Empirical Performance Analysis.

Cross-Cultural Comparative Stu.

INSTITUTIONAL FACTORS THAT PER.

Nutrient Transport by Shrimp H

DOES NEED FOR COGNITION MODERA.
Last Event

Accepted

Accepted

Accepted

Accepted

Initial submissio

Accepted

Accepted

Accepted

Initial submission

Accepted

Accepted

Accepted

Accepted

Accepted

Accepted

Accepted

Accepted

Accepted

Accepted

Accepted

Accepted

Revision u

Accepted

Accepted
Date of Last Event Waiting for Administrator

Mon May 132013

Mon May 132013

non 132013

Mon May 132013

Mon Apr 292013

Mon May 132013

Mon May 132013

Mon May 132013

Mon Apr 222013

Mon May 132013

Mon May 132013

Mon May 132013

Mon May 132013

Mon May 132013

Mon May 132013

Mon May 132013

Mon May 132013

Tue Jan 222013

Tue Jan 222013

Tue Jan 222013

Tue Jan 222013

152013

Tue Jan 222013

Tue Jan 222013
Type

Doctoral Project

Doctoral Dissertation

Doctoral Dissertation

Master's Thesis

- Master's Thesis

Doctoral Dissertation

Master's Thesis

Master's Thesis

Master's Thesis

Master's Thesis

Master's Thesis

Master's Thesis

Master's Thesis

Master's Thesis

Master's Thesis

Doctoral Dissertation

Master's Thesis

Master's Thesis

Master's Thesis

Masters Thesis

Master's Thesis

laster's Thesi

Doctoral Dissertation

Master's Thesis

Master's Thesis
Locked by Administrator Submitted

2013-05-07

2013-05-05

2013-05-03

2013-04-30

2013-04-29

2013-04-29

2013-04-24

2013-04-23

2013-04-22

2013-04-19

2013-04-18

2013-04-18

2013-04-12

2013-04-05

2013-03-28

2013-03-04

2013-01-17

2012-12-14

2012-12-14

2012-12-14

2012-12-13

2012-12-13

2012-12-13

2012-12-11

2012-12-10 
(2) Most Visited (3) Getting Started y Dictionary.com | Find t... University of North Flo... EZproxy Administration $\$$ Library Instruction Cal...

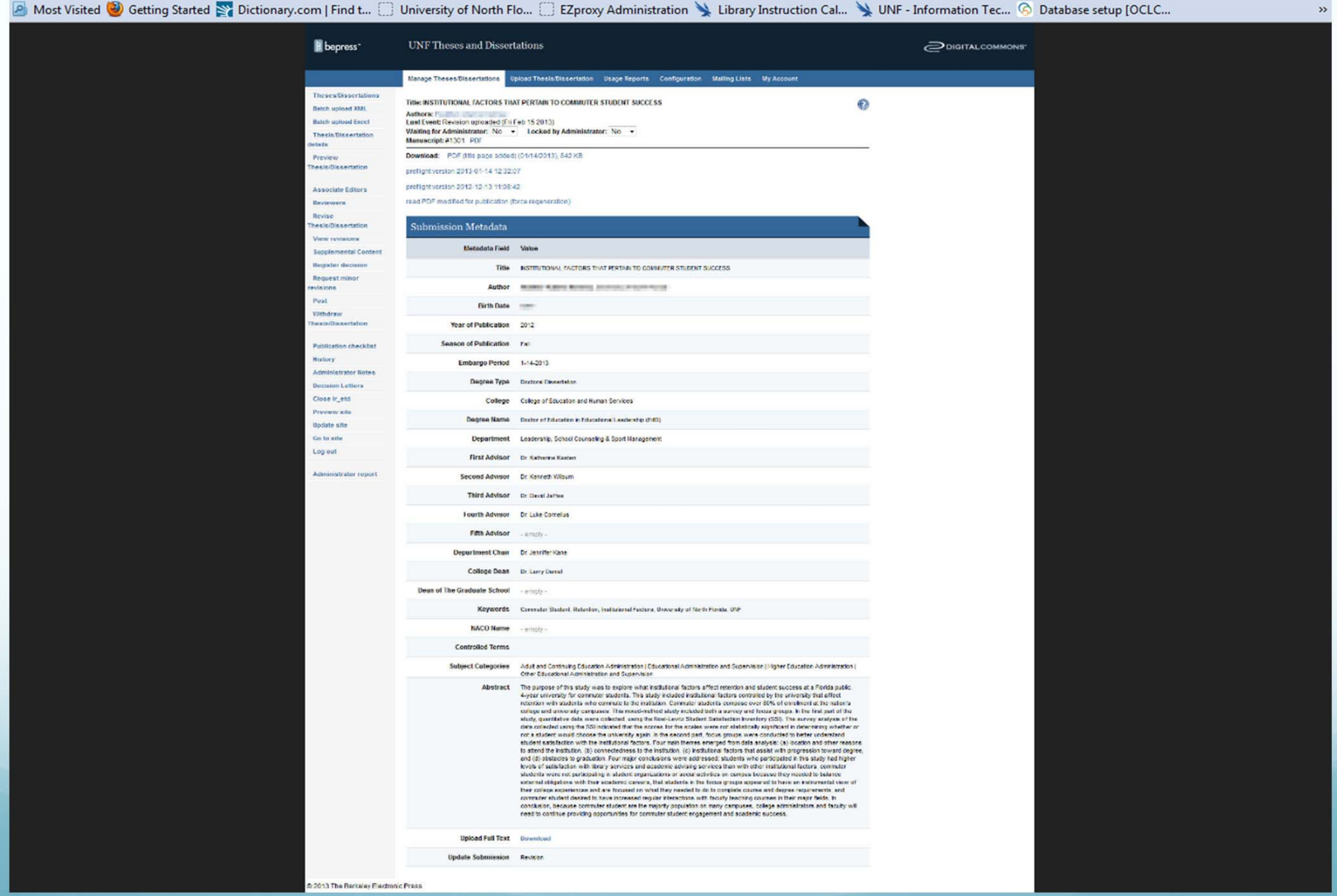




\section{Benefits}

- Library can track progress

- Paperless system

- Cost savings

- Quicker accessibility

- Increased viewing 


\section{Open Access}

- HathiTrust

- Journals in Digital Commons

- DOAJ, ArXiv, PubMed 


\section{Open Access Journals}

Report Range:

01 Oct 2011 to 30 Apr 2013

\section{Link Out By Target}

\section{Link Name}

DOAJ (Article) - (ISSN)

PubMed Central (Article)

PubMed Central - EISSN (Article)

DOAJ (Journal)

\section{Link Text}

Look for this article in the Directory of Open Access J ournals

Check PubMed Central for the full text of this article

Check PubMed Central for the full text of this article

Browse this journal at the Directory of Open Access J ournals

\section{Category}

Requests

Full Text

3559

Full Text

584

Full Text

Full Text 


\section{Benefits}

- Cost

- Becoming more reputable

- Reinforces role of library

- Encourages research 


\section{LibGuides}

- Liaisons

- Communication tool

- http://libguides.unf.edu/openaccess 


\section{Challenges}

- Open access costs

- University mandate

- Impact factors

- Interest

- Accessibility and permissions

- Metadata reliability

- Staff 


\title{
Renovation of Space to Promote Scholarly Communication
}

\author{
Cynthia J. Jordan, MLIS
}




\section{Why Change?}

- Transition from Print to Electronic Resources:

- 2008/09-1,901 total serial subscriptions. 1,692 are print.

- 2009/10 $-1^{\text {st }}$ Serials review of all active subscriptions by the Head of Serials and the Director of Public Services results in a drop in total serial subscriptions to 1,507 .

- 2010/11—Subscriptions continue to fall due to budget cuts to 1,302 .

- 2011/12-2 $2^{\text {nd }}$ Serials Review for elimination of duplication-another bad budget year-results in a cutback to 1,039.

- 2012/13--January 2013 after further elimination of duplication, library has 804 active serial subscriptions. Of those only 314 are print/electronic or print only serials.

- Weeding continues in the Periodicals area, Print Indexes, Bibliographies, replacing these with items online in our databases. 


\section{Why Change?}

- How could we promote scholarly communication within the library?

- What were faculty \& student needs that we were not meeting?

- Needs were changing--Music faculty and Computer Science faculty presented us with a proposal for a multi-media individual and group lab. 


\section{What To Do??}

- What to do with leftover space in the Periodicals ( $3^{\text {rd }}$ floor) of the library?

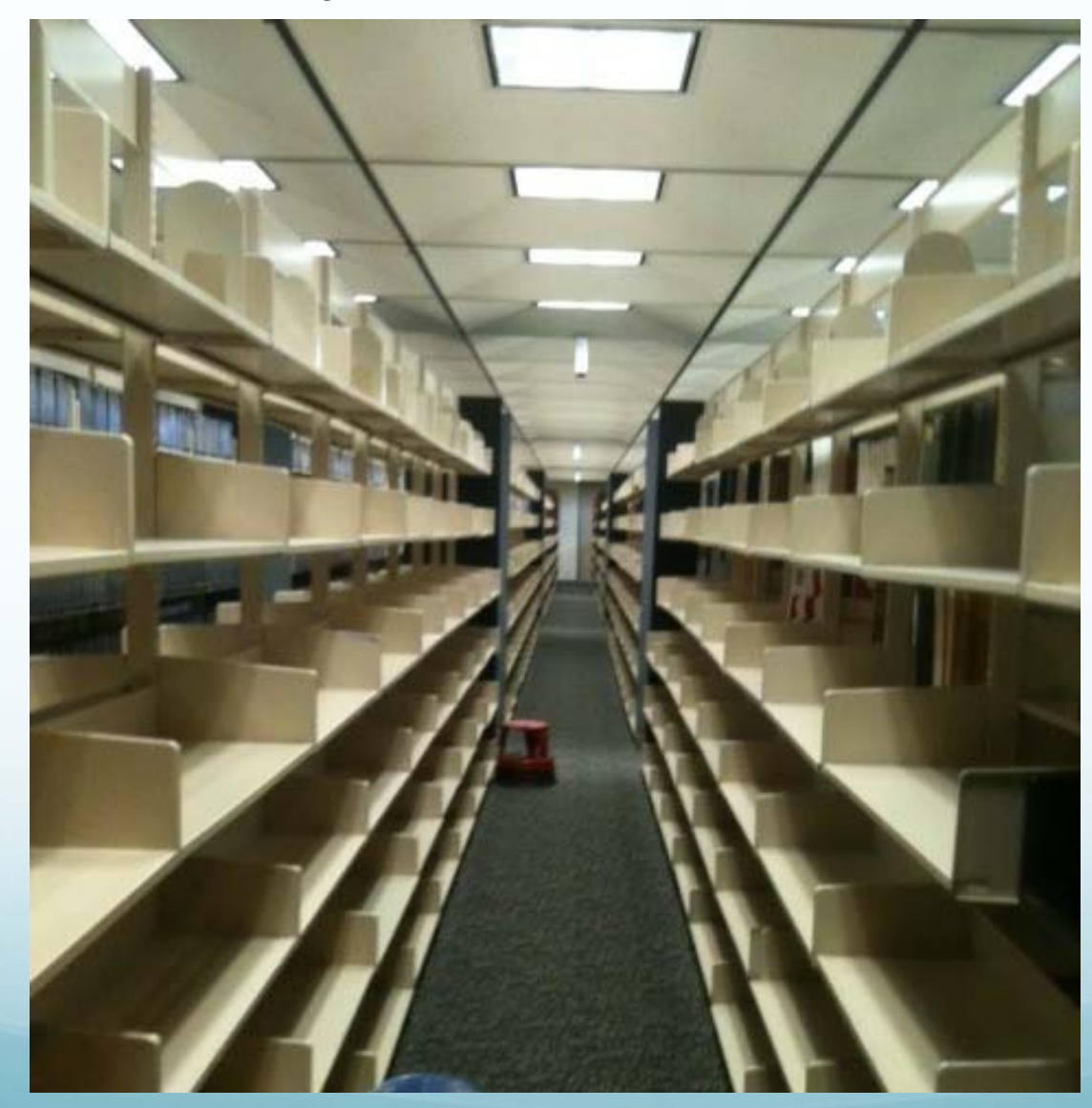




\section{Multi-Media Music Lab}

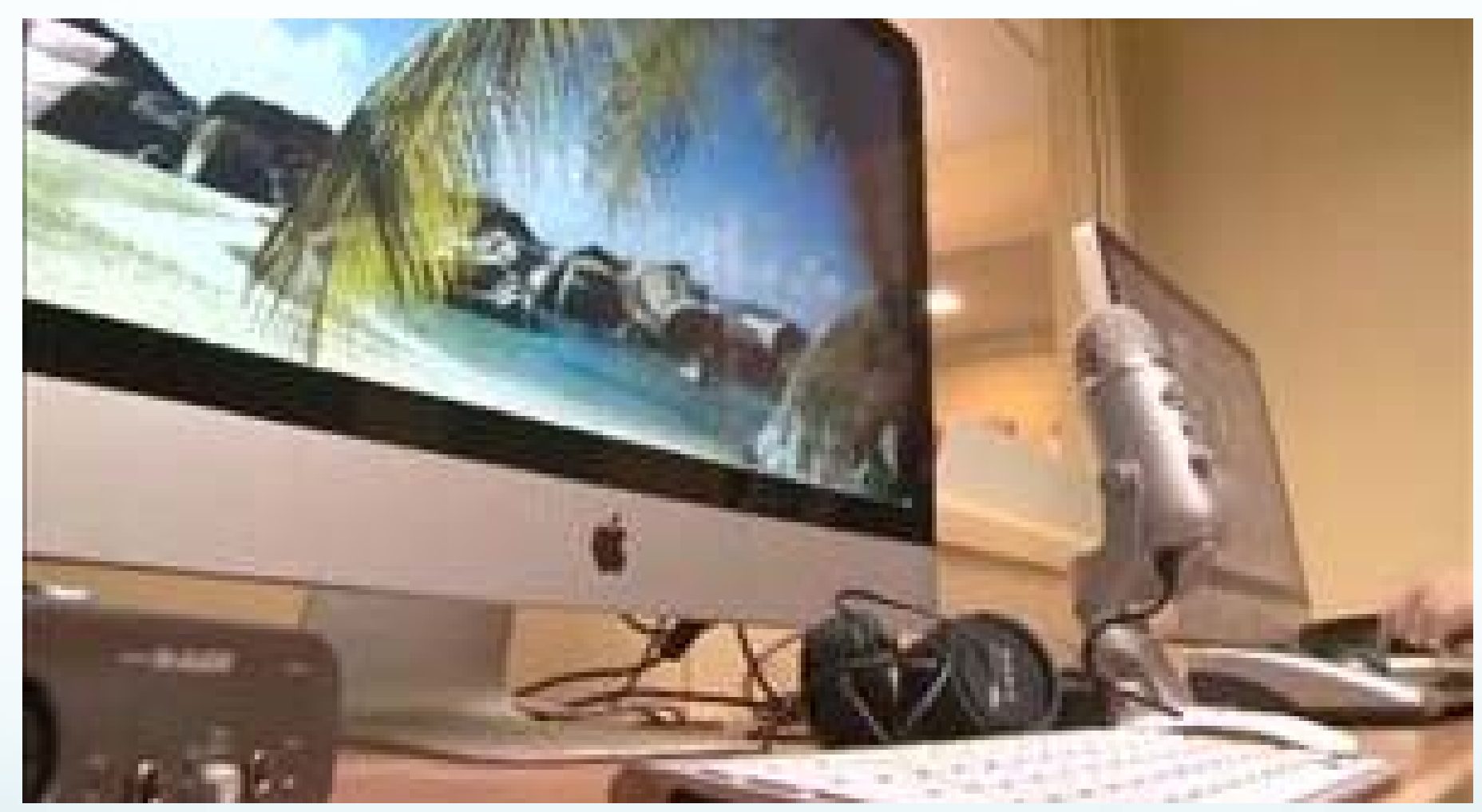

Photo courtesy of Auburn University 


\section{Reasons to Propose Project}

- There is space on the third floor for this project.

- The music and media collection is being transferred to the third floor of the library.

- UNF has an Internationally known jazz program in the music department. Faculty in the Music and Computer Science programs would use and are in favor of this project.

- Library Administration, Systems, and Faculty Librarians were consulted and are in favor of this proposal.

- This lab could draw people back into the library. 


\section{Where To Place It?}

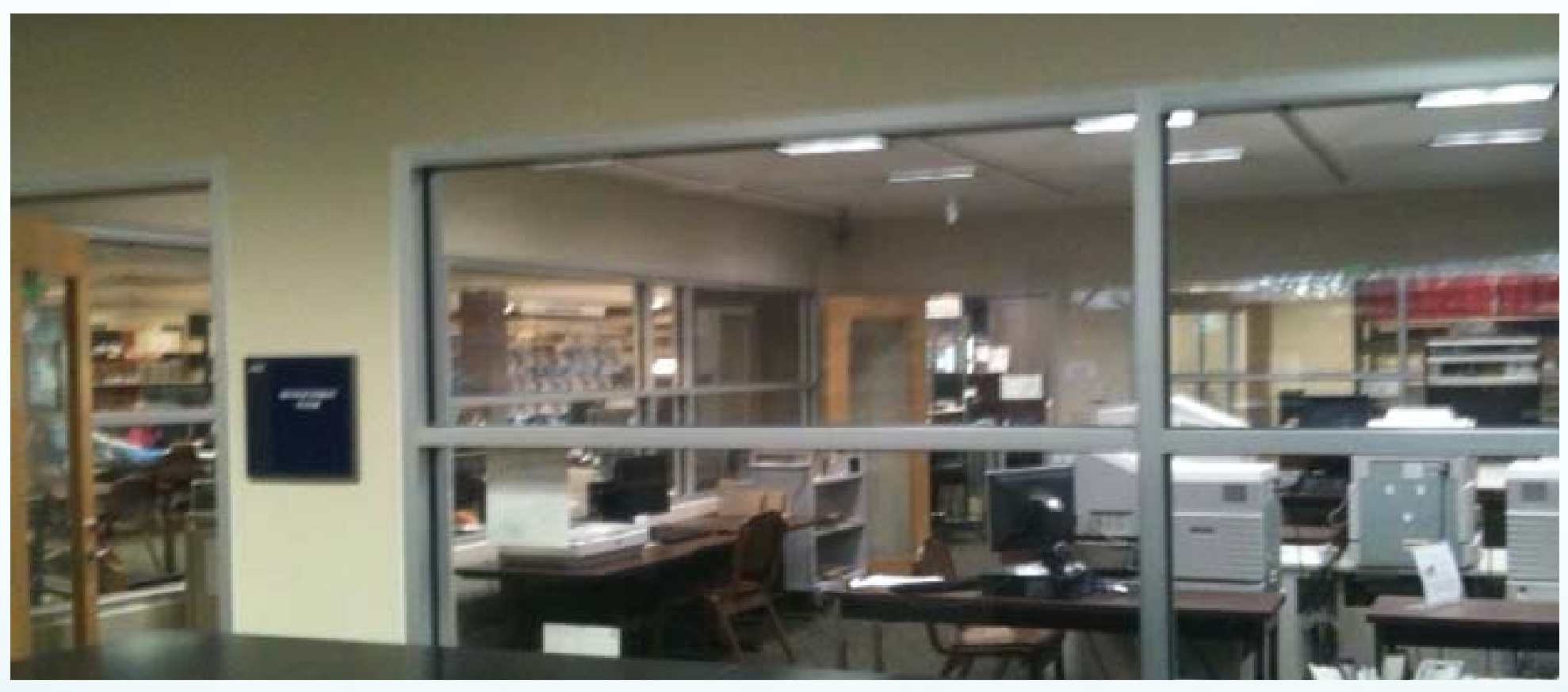




\section{Other Locations}
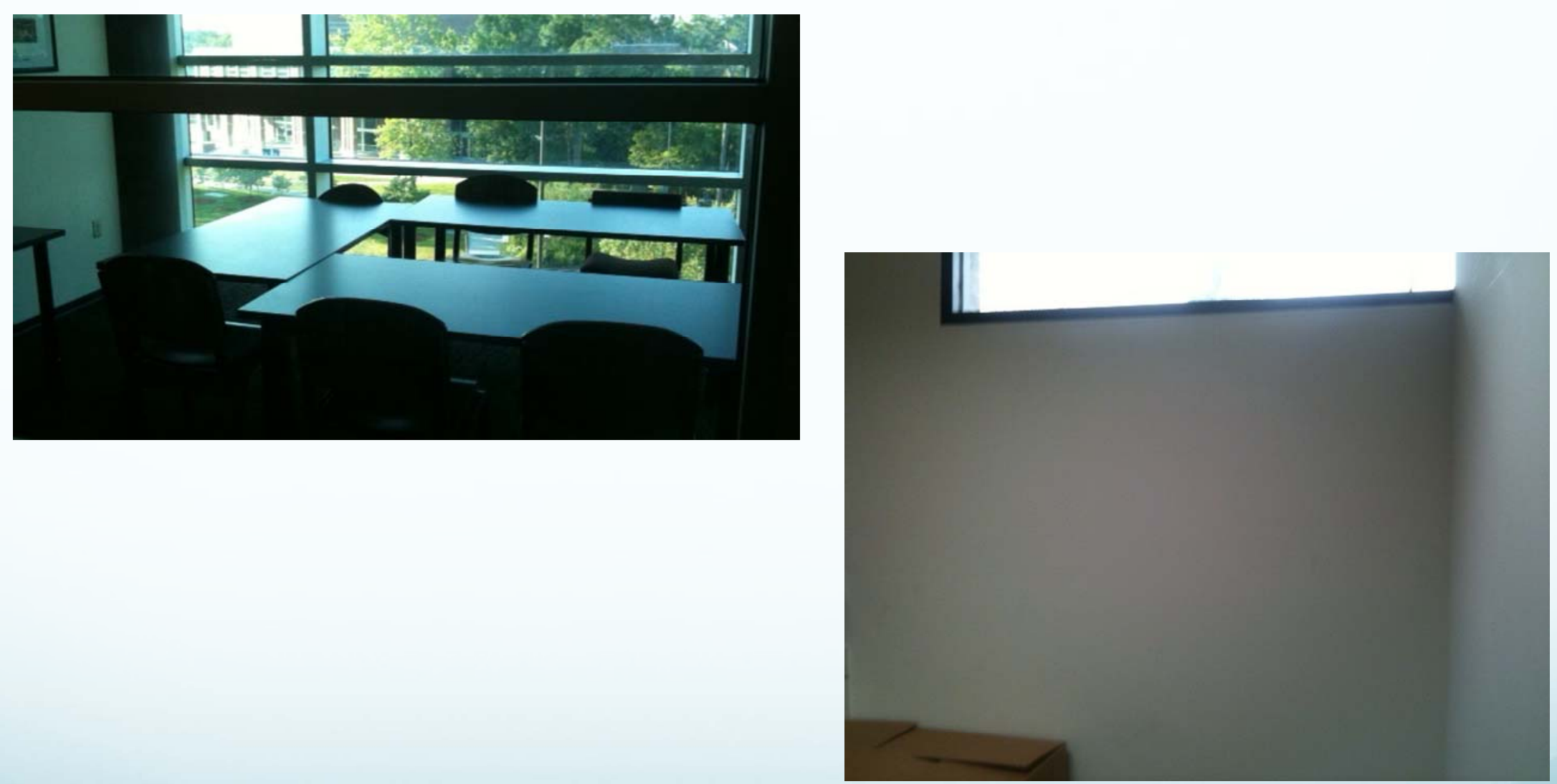


\section{What About Microform Machines?}

- Usage has been going down they could be relocated to our newspaper alcove. . .

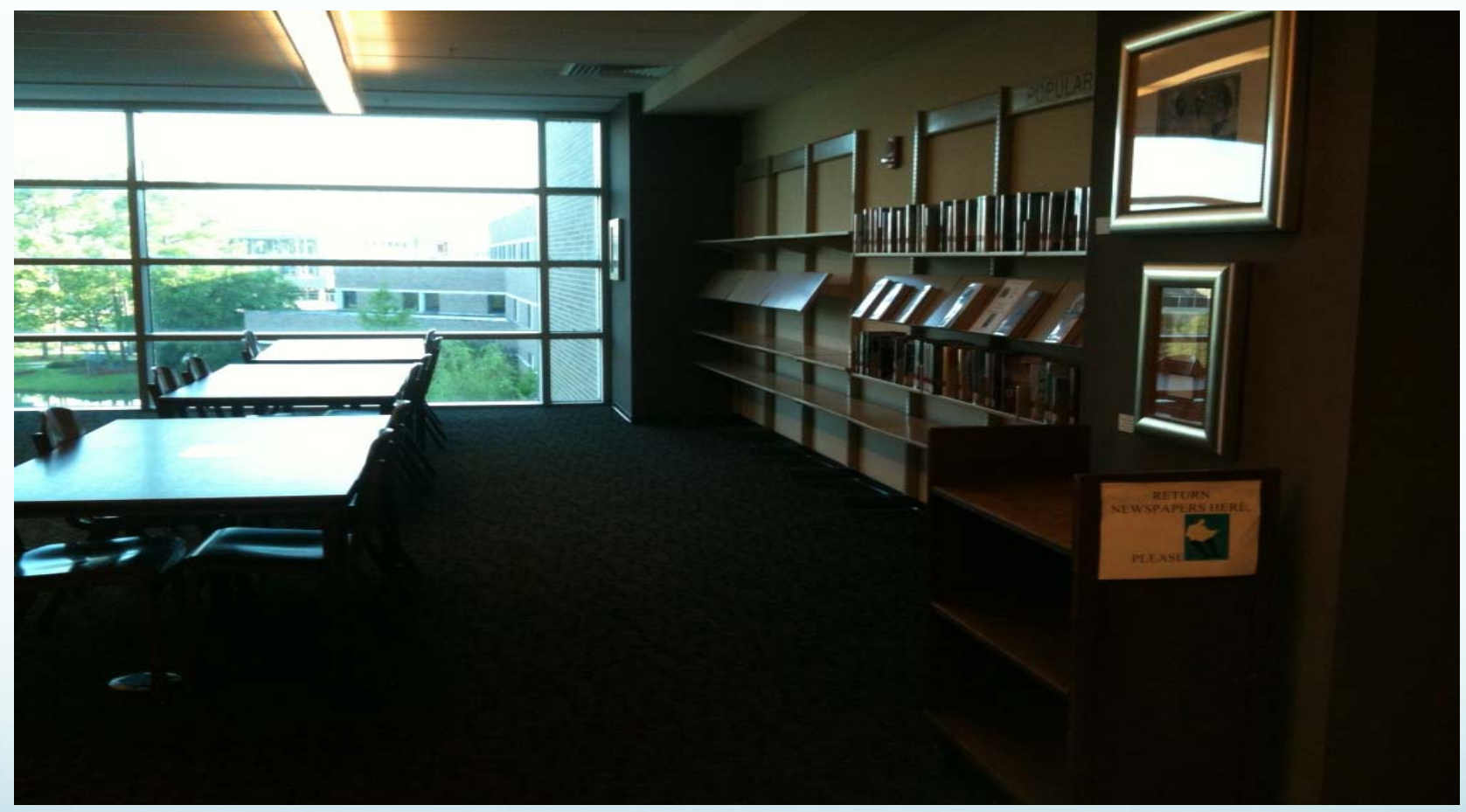




\section{Items for the Lab}

- Music Software (listening and editing) for the Computers already in the room. Tabletop Computer with software for creating, editing, and listening to music with a link to the library's EDS for research, seating \& tables.

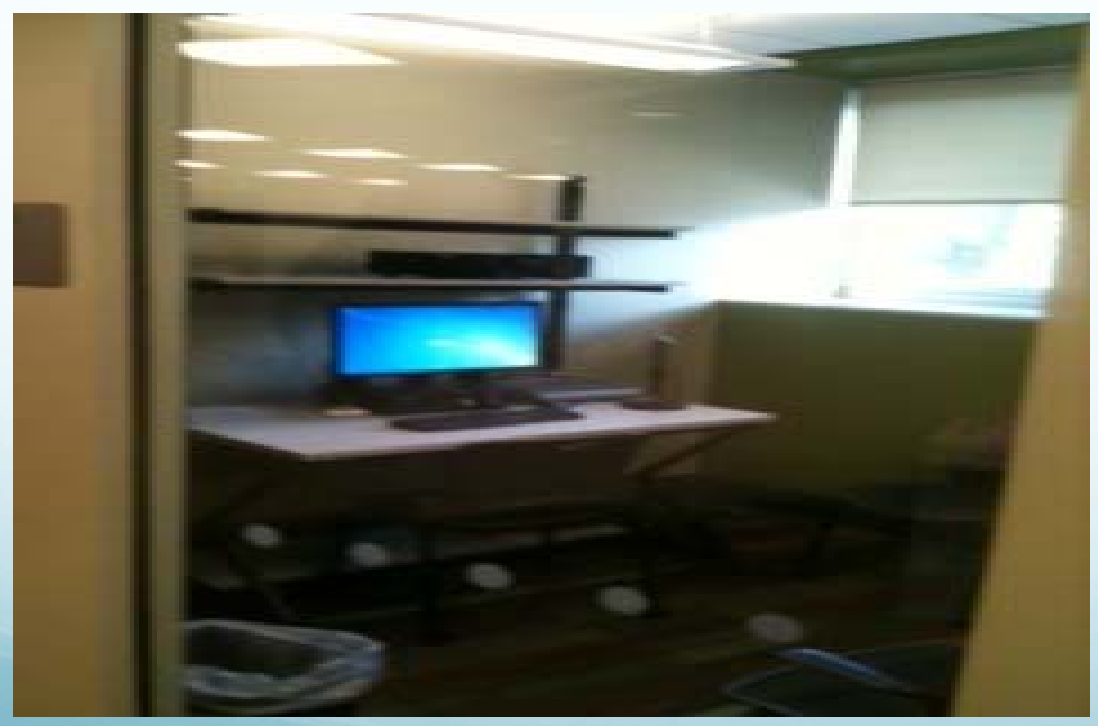




\section{Items for the lab}

- Soundproof Group Listening/Viewing Area with the appropriate equipment and seating for small groups (10 or fewer students and faculty) to show/view concerts, or listen to music (LP's, etc.) the way they were originally intended to be presented.

Photo courtesy of

Strozier Library,

Florida State

University

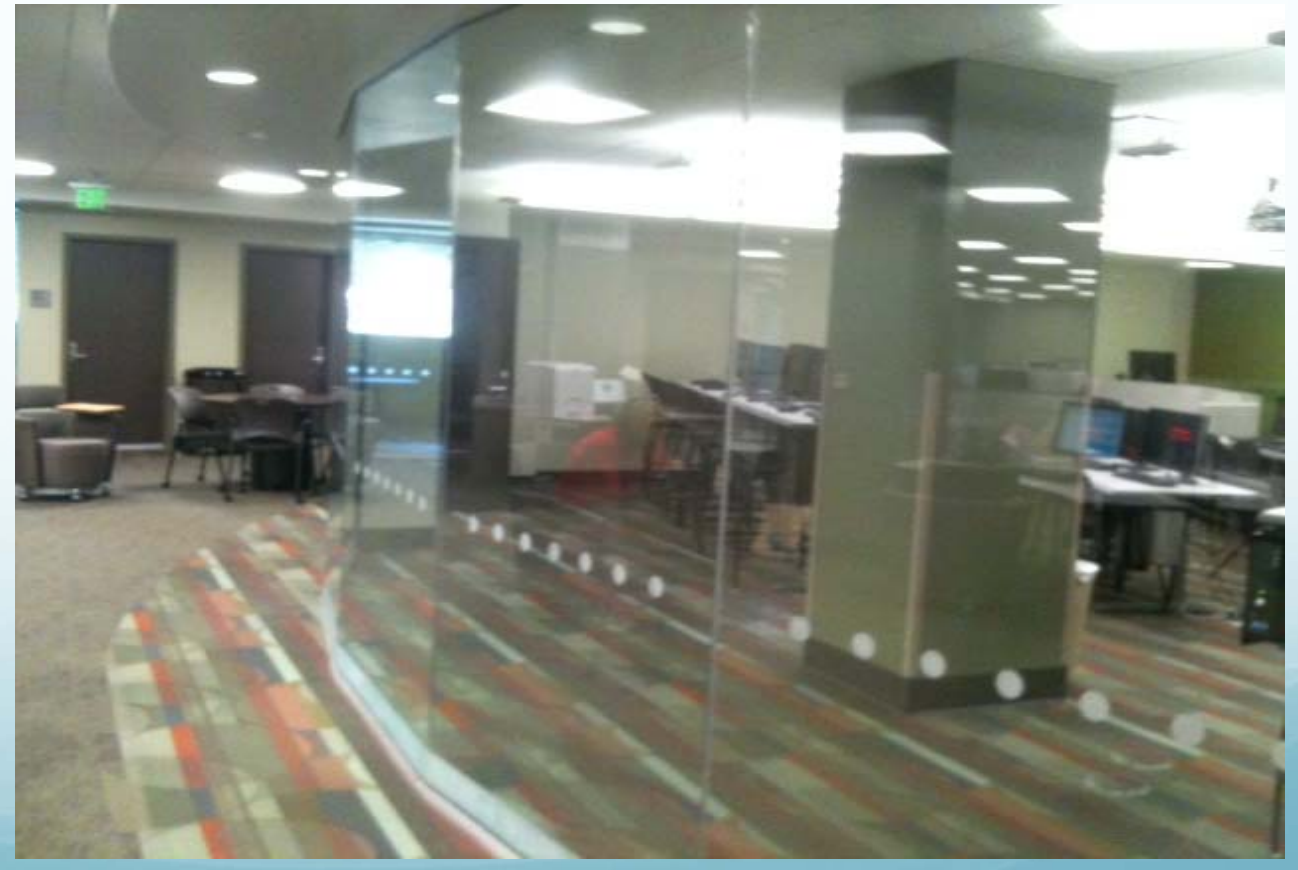




\section{Challenges}

- Money-The lab would have to be soundproofed.

- Applying for grants now.

- State money is tight-no new monies for building renovation.

- Library Leadership is changing.

- New Head of Public Services

- New Library Dean

- University Approval

- Contract bidding for approval

- Retirement 


\section{Why It Makes Sense}

- Library has to change the way it meets the scholarly communication needs of its patrons to remain vibrant and relevant.

- University faculty and students want this lab.

- The music and media collection will be located on the third floor of the library. This collection includes 23,942 CD/LP units and 11,321 videos/DVD's. A multi-media lab would bring people there to collaborate, create, and communicate.

- Other Libraries and Schools are creating the collaborative multi-use labs. 


\section{Conclusions}

- Discover a need that is not being met on your campus that would be a good fit for your library.

- Collaborate, Collaborate, Collaborate with:

- Librarians \& Library Staff

- Faculty \& Students

- University Administration and Building Personnel

Pursue your project with passion and optimism!! 


\section{References}

- ACRL Scholarly Communications Committee. (2003, June). Principles and Strategies for the Reform of Scholarly Communication 1. American Library Association Conference, Toledo Ohio, June 24, 2003. Retrieved from http://www.ala.org/acrl/publications/whitepapers/principlesstrategies

- Digital Music Lab (DML). (2011). Columbia University Libraries. Retrieved from http://library.columbia.edu/indiv/music/music lab.html

- Howard, J. (2013, February). White House Delivers New Open-Access Policy That Has Activists Cheering. Chronicle of Higher Education. Retrieved from http://www.chronicle.com/article/White-House-Delivers-New/137549

- Jordan, C.J. (2013). Reallocation of Space on the Third Floor, Thomas G. Carpenter Library. Unpublished manuscript, Thomas G. Carpenter Library, University of North Florida, Jacksonville, Florida.

- Lewis, D.W. (2013, March). From Stacks to Web: The Transformation of Academic Library Collecting. College \& Research Libraries, 74(2), 159-177.

- McCreless, P. (2011). Oxford School gets 'Ferrari' of Music Labs. Retrieved March 11, 2013 , from

http://www.annistonstar.com/printer friendly/14744804 


\section{References}

- Montag, M., Sullivan, S., Dickey, S., \& Leider, C. (2006). Proceedings from the $12^{\text {th }}$ Meeting of the International Conference on Auditory Display: A Low-Cost, LowLatency Multi-Touch Table With Haptic Feedback for Musical Applications. Oslo, Norway. NIME, 11, (May 30-June 2011), 217-222.

- Peterson, A.T., Emmett, A., Greenberg, M.L. (2013). Open Access and the Author-Pays Problem: Assuring Access for Readers and Authors in a Global Community of Scholars. Journal of Librarianship and Scholarly Communication, 1(3)e, 1064. http://dx.doi.org/10.7710/2162-3309.1064

- St. Petersburg College. (2012). Facilities, Music Technology Lab. Retrieved from http://www.spcollege.edu/pages/dynamic.aspx?id=2922

- UNF Digital Commons. (2013). Retrieved from http://digitalcommons.unf.edu/

- University of North Carolina, Ashville. (2013). From Strings to Synthesizers. UNC Ashville. http://www.unca.edu/features/strings-synthesizers

- Walters, T.O. (2007). Reinventing The Library-How Repositories Are Causing Librarians to Rethink Their Professional Roles. Libraries and the Academy, 7(2). Retrieved from http://hdl.handle.net/1853/14421 


\section{For More Information. . .}

- Alice Eng, MLIS

Thomas G. Carpenter Library

University of North Florida

Jacksonville, FL 32224

alice.eng@unf.edu

- Cynthia J. Jordan, MLIS

Thomas G. Carpenter Library

University of North Florida

Jacksonville, FL 32224

cjordan@unf.edu 